\title{
PENGALAMAN MENGKONSUMSI BERITA ONLINE: PERSPEKTIF GENERASI MILENIAL DI JAWA TENGAH
}

\author{
Prinisia Nurul Ikasari, Lintang Citra Christiani \\ Universitas Tidar
}

\begin{abstract}
Most of the people who access the internet are millennial generation, that is, the generation born between 1982 and 2000 . Digitalization forces the mass media in Indonesia to participate in meeting the demands of society's need for up to date information. This study aims to examine the practices of the millennial generation in consuming online news. In particular, this study aims to reveal the diversity of meanings that arise from the experiences of audiences when consuming online news. This study applies a qualitative approach to the reception method. The comment column provides a reference space for itself to continue consuming the next news activity on the mass media or not. Comments can even be termed as a filter for news that millennial generation will consume. Storytelling as millennial generation's online news consuming experience. From the point of view of millennials storytelling helps facilitate their imagination through visual means.
\end{abstract}

\section{Keywords}

(Millenials, News, Media Use)

Correspondence Contact prinisia.nurul@untidar.ac.id

\section{PENDAHULUAN}

Digitalisasi, era baru perubahan informasi yang kini terus berkembang mengikuti perkembangan teknologi. Di Indonesia setidaknya tiga jam per hari masyarakat mengakses internet melalui smartphone-nya. Sebagian besar masyarakat yang mengakses internet merupakan generasi milenial, yakni generasi yang lahir pada rentang tahun 1982 hingga 2000. Generasi ini memang dibesarkan oleh kemajuan teknologi dari waktu ke waktu sehingga tak heran jika selalu melibatkan teknologi dalam setiap aspek kehidupannya (Howe dan Strauss dalam Putra, 2017: 18). Generasi ini juga sering disebut sebagai digital native dimana generasi yang hadir ketika teknologi digital muncul dikehidupan masyarakat. Digital native (Palfrey, 2008), mempunyai akses terhadap jaringan sosial digital dan juga memiliki keahlian untuk menggunaan teknologi tersebut (Dalam Rusadi,2014: 176).

Sementara itu pemerintah saat ini fokus pada Gerakan 100 Kota Pintar (smart city) yang mengedepankan ketersediaan akses informasi bagi publik, salah satunya adalah adanya pojok milenial pada ruang publik yang diimplementasikan dalam bentuk akses free wifi. Kota Semarang adalah titik pusat dari perkembangan smart city di Jawa Tengah. Selain itu, Kota Magelang juga didaulat menjadi kota percontohan smart city (Amanda, 2019). Dengan kemudahan akses itu, generasi milenialnya pada saat yang sama menjadi pengkonsumsi setia dari internet.

Digitalisasi memaksa media massa di indonesia untuk turut memenuhi tuntutan kebutuhan masyarakat akan informasi yang up to date. Media massa melakukan adopsi digital untuk mengimbangi kebutuhan masyarakat akan efisiensi dan kecepatan informasi. Masifnya penggunaan internet sebagai bahan informasi oleh generasi milenial menuntut media massa untuk melakukan penyesuaian pada struktur organisasi. Jurnalis di dalam news room kini bersirkulasi dari pola kerja yang dulu menghasilkan informasi dalam rentang harian menjadi 
menit dan bahkan detik. Tuntutan akan kecepatan pun "menghantui" jurnalis. Demi mengejar kecepatan tidak jarang jurnalis terjebak pada kegiatan copy-paste informasi dari rekan media lainnya atau bahkan media sosial yang belum tentu bisa dipertanggungjawabkan kebenarannya. Belum lagi fenomena click bait jurnalism, yang mana media massa dengan kesadaran menarik minat pembaca melalui judul dan tema yang menipu guna meraup penghasilan iklan (Hartley, 1996: 32)

Digitalisasi seringkali berbenturan dengan kaidah jurnalistik bagi penulisan berita. Hasil penelitian Garini dan Besman (2018) menunjukkan bahwa praktik jurnalisme kloning dilakukan wartawan karena beberapa faktor, yang di antaranya meliputi kerjasama dan solidaritas antar rekan wartawan, tuntutan pekerjaan wartawan media online untuk menghasilkan berita sebanyak-banyaknya dalam waktu sesingkat-singkatnya, kinerja individu wartawan, regulasi perusahaan media, dan perkembangan teknologi. Namun hal ini tetap dilakukan oleh industri media demi dapat bertahan hidup. Digitalisasi seringkali berbenturan dengan kaidah jurnalistik bagi penulisan berita. Namun hal ini tetap dilakukan oleh industri media demi dapat bertahan hidup. Dalam hal ini, sebenarnya khalayak khususnya generasi milenial sebagai pengkonsumsi media yang paling banyak menerima efeknya. Namun selama ini perpektif dari khalayak justru tidak terungkap. Secara makro, Penelitian ini bertujuan untuk mengkaji pengamalan generasi milenial dalam mengkonsumsi berita online. Secara khusus penelitian ini ingin mengungkap keberagaman makna yang muncul dari pengalaman khalayak ketika mengkonsumsi berita online

\section{KAJIAN TEORITIK}

\section{Uses and gratification}

Adanya digitalisasi membuka ruang pada keberagaman media massa di Indonesia. Penikmat media massa di era ini menggunakan media massa karena memiliki tujuan tertentu. Dimana pengguna media bersifat aktif, dan terbiasa memenuhi kebutuhan akan informasi dengan tindakan memilih media mana yang mereka akan gunakan (uses) guna mendapatkan kepuasan (gratification) tertentu. Menurut Charney dan Greenberg (2000) terdapat tipologi kepuasan (gratification) dalam penggunaan media yakni, agar pengguna media tidak ketinggalan sebuah berita atau informasi (keep in formerd), pemenuhan akan hiburan bagi diri, identifikasi dengan peer group atau sebayanya, pencarian rasa nyaman, dan adanya kepentingan aktivitas komunikasi (dalam Karman, 2013:94).

Dalam komunikasi massa uses and gratification memiliki prinsip dasar bahwa pengguna media memiliki otonomi untuk memilih dan menggunakan media massa. Katz, Blumer, dan Gurevitch (1974) menjelaskan asumsi dasar dari uses and gratification bahwa pengguna media aktif dan memiliki tujuan tertentu, dalam proses komunikasi massa terdapat inisiatif pemuasan kebutuhan pada pengguna media massa, dan media massa bersaing untuk dapat memuasakan penggunanya (Rahmat,2011: 203). Uses and gratification pada dasarnya berjalan dari berbagai cara, melalui: 


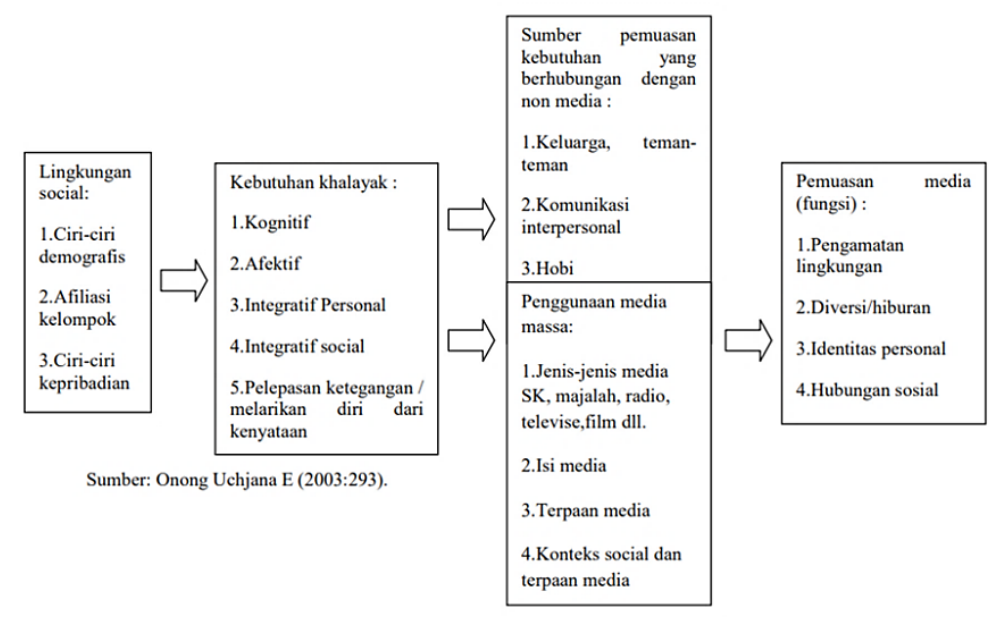

(Onong Uchyana E, 2003: 293)

\section{Kovergensi Media di Indonesia}

Konvergensi media merujuk pada kolaborasi antara teknologi komputer dan komunikasi yang dinaungi pada semua industri media massa. Dalam industri media konvergensi menyatukan tiga komponen penting yakni computing, communication, dan content yang merupakan konsekuensi langsung dari proses digitalisasi (Baran, 2012; 404-406). Dunia digital memang memiliki keunggulan akan kecepatan dan terbebas akan ikatan waktu, dan konvergensi media memang menjadi strategi bagi media massa untuk mendapatkan keuntungan financial bagi perusahaan media. Kolaborasi akan terwujudnya konsentrasi perusahaan media, serta digitalisasi memang tidak dapat dipungkiri dikala regulasi mengenai media memungkinkan untuk itu. Hasilnya kolaborasi ini justru mendukung atas terbentuknya informasi yang memiliki sudut padang homogen pada sebuah isi berita. Belum lagi tuntutan yang besar pada jurnalis memungkinkan terjadinya jurnalisme kloning atau copypaste jurnalism. Kondisi ini justru memperburuk kondisi informasi yang akan diterima oleh pengguna media sosial yakni generasi milenial.

Generasi yang lahir dikurun waktu 1982 sampai 2000 ini merupakan generasi yang hidup dipergantian milenium dan bersamaan dengan perkembangan teknologi digital. Generasi ini memiliki kebiasaan dalam menggunakan teknologi komunikasi yang instan seperti SMS, media sosial dan juga instant messaging. Dalam mendapatkan informasi pun generasi ini mengalami perubahan teknologi media massa yakni perubahan dari media massa konvensional ke digital.

\section{Storytelling}

Dalam sejarah komunikasi, storytelling merupakan salah jenis komunikasi yang paling tua. Penggunaan gaya cerita atau naratif yang dikombinasi dengan beberapa elemen komunikasi merupakan cara storytelling dalam melakukan komunikasi. Storytelling merupakan sebuah alat komunikasi yang efektif untuk digunakan dalam produk komunikasi, namun pemilihan sudut pandang dan cerita harus dipilih secara benar dan sesuai dengan keadaan nyata atau fakta dilapangan. Storytelling jauh lebih dipercaya sebagai sebuah informasi karena dianggap mampu menyentuh perasaan dan pikiran khalayak, hal ini disebabkan dalam elemen komunikasi storytelling menuntut kejujuran, otentitas, dan kredibilitas sebagai elemen kritis yang memperhatikan juga isu moral dan etika (Matthew dan Wacker, 2007). Storytelling biasanya dimulai dengan melihat sebuah masalah, kemudian merangkainya menjadi sebuah cerita yang bisa menarik khalayak dengan emosi dan juga pemahaman (Bryan, 2011:13), 
dengan begitu pesan akan mudah tersampaikan dan di ingat. Untuk dapat membagikan sebuah informasi yang mengandung ilmu pengetahuan maka diperlukan Storytelling yang fokus pada permasalahan yang ada di masyarakat dan kemudian nantinya ditunjukan secara detail bagaima hal tersebut bisa diatasi dan diperbaiki dengan penjelasan solusi (Melissa, 2012:15).

\section{METODOLOGI}

Penelitian ini merupakan riset dengan studi khalayak sebagai fokusnya. Logika pemikiran yang digunakan adalah paradigma konstruktivisme yang menempatkan subyek, dalam hal ini khalayak media sebagai pusat dari kegiatan komunikasi. Pengalaman khalayak dalam mengkonsumsi berita online dipahami sebagai hasil dari konstruksi sosial, yang mana kebenaran dari realitas sosial tersebut bersifat relatif. Khalayak merupakan cultural agent yang aktif mengasilkan makna dari wacana yang ditawarkan media (Imran, 2012: 51). Dengan demikian, pengalaman khalayak dalam mengkonsumsi berita online dipahami muncul dari alasan-alasan subyektif bukan karena realitas obyektif semata.

Penelitian ini menerapkan pendekatan kualitatif dengan metode resepsi. Metode resepsi ini adalah bagian dari studi khalayak yang berupaya menggali bagaimana proses wacana media dikaitkan dengan latar belakang budaya khalayaknya. Menurut Jensen (dalam Pearson, 2013: 35-37, ada tiga elemen pokok dari metode resepsi, yakni pengumpulan data (the collection), analisis data (analysis), dan interpretasi data (the interpretation of reception data). Pada tahap pertama, akan dikumpulkan data dari khalayak tentang pengalaman sehari-hari dalam mengkonsumsi media online, khususnya berita. Sehingga didapatkan data-data mengenai isuisu yang sedang berkembang dan dibincangkan oleh khalayak.

Pada tahap kedua, data-data dari khalayak termasuk di dalamnya komentar dan berbagai pernyataan serta perbedaan pendapat dari khalayak ditelaah dan dikodifikasi sesuai dengan keberagaman makna yang muncul tersebut. Selanjutnya di tahap ketiga temuan tersebut dianalisis dan diinterprestasi. Dalam tahap analisis keberagaman makna tersebut mungkin sekali tetap ada karena justru dalam penelitian ini berupaya memunculkan penerimaan khalayak secara riil di lapangan.

Penelitian ini dilakukan di Kota Magelang dan Kota Semarang yang merupakan dua kota di Jawa Tengah yang berkomitmen untuk menjadi smart city. Berdasarkan data, Kota Magelang telah menjadi kota percontohan smart city dengan kategori kota sedang, yang mana kota tersebut menyediakan fasilitas akses informasi di setiap ruang publik. Pada penelitian ini khalayak yang diteliti beragam dalam pendidikan, pekerjaan, budaya, dan rentang usia mulai 19 hingga 37 tahun (generasi milenial) dimana terdapat 7 khalayak yang telah diteliti dengan kategorisasi sebagai berikut: 


\begin{tabular}{|c|c|}
\hline Karakteristik Khalayak Penelitian & Jumlah \\
\hline $\begin{array}{ll}\text { - } & \text { Usia: 19-24 Tahun } \\
\text { - } & \text { Mahasiswa } \\
\text { - } & \text { Usia 25-30 Tahun } \\
\text { - } & \text { Karyawan Swasta }\end{array}$ & $\begin{array}{l}2 \\
1\end{array}$ \\
\hline $\begin{array}{ll}\text { - } & \text { Usia 30-37 Tahun } \\
\text { - } & \text { Dosen } \\
\text { - } & \text { Usia 30-37 } \\
\text { - } & \text { Pengusaha/Wirausaha } \\
\text { - } & \text { Usia 30-37 } \\
\text { - } & \text { Ibu Rumah Tangga }\end{array}$ & $\begin{array}{l}1 \\
1 \\
2\end{array}$ \\
\hline
\end{tabular}

Dari pertemuan dan tatap muka tersebut pada tahap pertama, telah dikumpulkan data dari khalayak tentang pengalaman sehari-hari dalam mengkonsumsi media online, khususnya berita. Peneliti membatasi khalayak yang diteliti adalah khalayak yang secara aktif mengkonsumsi berita secara online setiap hari, baik lewat aplikasi, website, maupun media sosial. Selain itu pembatasan juga dilakukan dengan memilih khalayak yang mengikuti satu atau lebih situs atau aplikasi berita berikut ini, yaitu Suara Merdeka, Kompas Grup, atau Detik. Media-media tersebut dipilih karena ketiga media itu termasuk situs yang paling banyak dikunjungi.

\section{HASIL DAN PEMBAHASAN}

Perubahan bentuk media adalah sebuah keniscayaan yang akan selalu terjadi seiring dengan perkembangan teknologi. Kehadiran internet menjadi tantangan tersendiri bagi media massa konvensional saaat ini (cetak maupun elektronik). Media massa digital menjadi solusi atas tantangan dan tuntutan masyarakat milenial saat ini. Perkembangan perangkat mobile, perkembangan internet serta perubahan pola masyarakat memaksa media massa melakukan konvergensi media.

Konvergensi media merujuk pada kolaborasi antara teknologi komputer dan komunikasi yang dinaungi pada semua industri media massa. Dalam industri media konvergensi menyatukan tiga komponen penting yakni computing, communication, dan content yang merupakan konsekuensi langsung dari proses digitalisasi (Baran, 2012 : 404-406). Dunia digital memang memiliki keunggulan akan kecepatan dan terbebas akan ikatan waktu, dan konvergensi media memang menjadi strategi bagi media massa untuk mendapatkan keuntungan financial bagi perusahaan media. Kolaborasi akan terwujudnya konsentrasi perusahaan media, serta digitalisasi memang tidak dapat dipungkiri dikala regulasi mengenai media memungkinkan untuk itu. Hasilnya kolaborasi ini malah menunjang atas terjadinya data yang mempunyai sudut padang homogen pada sebuah isi berita. Belum lagi tuntutan yang besar pada jurnalis memungkinkan terbentuknya jurnalisme kloning ataupun copypaste jurnalism. Keadaan ini malah memperparah kondisi informasi yang hendak diterima oleh pengguna media sosial yaitu generasi milenial.

Generasi yang lahir dikurun waktu 1982 sampai 2000 ini merupakan generasi yang hidup dipergantian milenium dan bersamaan dengan perkembangan teknologi digital. Generasi ini memiliki kebiasaan dalam menggunakan teknologi komunikasi yang instan seperti SMS, media sosial dan juga instant messaging. Dalam mendapatkan informasi pun generasi ini mengalami perubahan teknologi media massa yakni perubahan dari media massa konvensional ke digital. Baginya mendapatkan informasi secepatnya dapat dipenuhi dengan keikutsertaanya dalam media online. 


\section{Kini Pengguna Media Bersifat Aktif}

Generasi milenial memiliki kecenderungan untuk melihat berita dari sisi kebutuhan. Akses terhadap media online akan dilakukannya jika disaat itu dirinya memang membutuhkan berita yang terkait dengan kehidupan bersama dengan peer groupnya. Sebagian besar khalayak generasi milenial menyatakan bahwa keberadaan media online penting bagi dirinya karena dirasa paling cepat dalam memenuhi hasrat keingintahuannya terhadap informasi. Karena pada dasarnya terdapat kepuasan yang dicari ataupun diinginkan khalayak ketika mengkonsumsi suatu jenis media, dimana ini oleh Philip Palmgreen disebut sebagai Gratification Sought, dan juga pencapaian kepuasan nyata yang diperoleh seseorang khalayak setelah mengkonsumsi suatu media (Gratification Obtained) (Kriyantono, $2009: 210$ ).

\section{Generasi Millenial}

Saat ini generasi millenial sering di identikan dengan generasi yang memiliki peluang terbesar dalam revolusi industri 4.0. Sebagai pengguna aktif internet terbesar di Indonesia generasi ini memiliki andil pada perkembangan perubahan pola perilaku bermedia. Maka tak jarang generasi ini disebut sebagai generasi internet. Generasi memiliki definisi yang oleh Manheim disebut sebagai sebuah konstruksi sosial yang mana di dalamnya terdapat sekelompok orang yang memiliki kesamaan umur dan pengalaman sejarah yang sama (KPPPA, 2018: 13). Generasi millenial sendiri merupakan salah satu kelompok generasi berusia 19 hingga 34 tahun yang mana penamaan milenial itu sendiri pertama kali dikemukakan oleh William Strauss dan Neil dalam bukunya yang berjudul Millennials Rising: The Next Great Generation (2000). Generasi yang lahir pada rentang tahun 1980 sampai dengan 2000 ini disebut juga dengan generasi $\mathrm{Y}$.

Dibandingkan generasi sebelumnya, generasi millenial memiliki karakteristik yang berbeda. Salah satu karakteristik utama generasi milenial ditandai oleh adanya peningkatan penggunkaan komunikasi melalui media, serta teknologi digital. Karena dibesarkan oleh kemajuan teknologi, generasi milenial memiliki ciri-ciri kreatif, informatif, mempunyai passion dan produktif (KPPA,2018:18). Dibandingkan generasi sebelumnya, generasi millenial lebih berteman baik dengan teknologi. Bagi millenial teknologi mampu menjadikan dirinya sebagai individu yang lebih produktif dan efisien. Generasi ini mempunyai karakteristik komunikasi yang terbuka, gandrung terhadap media sosial bahkan cenderung fanatik, dalam kesehariannya sangat terpengaruh dengan perkembangan teknologi yang ada, serta lebih terbuka dengan pandangan politik dan ekonomi. Sehingga, mereka terlihat sangat reaktif terhadap adanya perubahan lingkungan yang terjadi di sekitarnya. Karenanya media online menjadi hal yang sangat dia butuhkan. Boston Consulting Group (BCG) bersama University of Berkley tahun 2011 (KPPA, 2018:18-20) melakukan penelitian terkait dengan generasi millenial dimana secara spesifik disebutkan bahwa:

1. Minat membaca secara konvensional kini sudah menurun karena Generasi $Y$ (Millenial) lebih memilih membaca lewat smartphone mereka

2. Millennial wajib memiliki akun sosial media sebagai alat komunikasi dan pusat informasi

3. Millennial pasti lebih memilih ponsel daripada televisi. Menonton sebuah acara televisi kini sudah tidak lagi menjadi sebuah hiburan karena apapun bisa mereka temukan di telepon genggam

4. Millennial menjadikan keluarga sebagai pusat pertimbangan dan pengambil keputusan mereka

Sedangkan tidak jauh berbeda generasi millenial di Indonesia khususnya di Jawa Tengah dimana ada beberapa keunggulan dari generasi milenial, yaitu ingin serba cepat, dinamis, 
melek teknologi, dekat dengan media sosial, dan hal ini terlihat dari bagaimana mereka mengkonsumis internet dengan lama durasi setiap harinya lebih dari 2 jam. Sebagai generasi yang ingin serba cepat mereka mengandalkan berita online sebagai media informasi rujukan. Generasi ini juga memilih media sosial sebagai media pertama untuk mengakses berita online tersebut. Ini jelas mencerminkan millennial yang wajib memiliki akun sosial media sebagai alat komunikasi dan pusat informasi. Selain itu mereka sering menjadikan peer groupnya sebagai pusat pertimbangan dan pengambil keputusan seperti memilih berita dan mencari informasi melalui online. Millenial lebih memilih untuk mengkonsumsi berita baik itu video, maupun tulisan dengan media online, mereka lebih memilih ponsel daripada televisi. Baginya ponsel dengan teknologi online mampu memberikan kepuasan dalam mendapatkan informasi. Melalui media online yang diakses melalui ponsel memudahkan mereka untuk tetap mendapatkan informasi yang cepat kapanpun disela-sela kesibukan mereka dalam kegiatan sehari-hari. Hal ini juga di buktikan dengan data persentase generasi milenial di Indonesia yang menggunakan telepon seluler HP atau Nirkabel pada tahun 2017 sudah mencapai 91,62 persen (KPPPA, 2018: 61).

\section{Karakteristik Media Online}

Berkembangan jurnalistik yang cukup kompleks membawa dampak pada perubahan bentuk media massa. Jumlah media online kita semakin beragam jika dibandingkan dengan media konvesional seperti cetak maupun penyiaran. Era konvergensi media membuat perusahaan media massa mau tidak mau melakukan sejumlah strategi. Media konvesional berlombalomba beradaptasi dengan strategi yang mengarahkan medianya secara online. Perubahan ini juga memberikan dampak pada perubahan karakteristik media massa. Jurnalisme online menjadi salah satu cara yang dilakukan, yakni dimana jurnalisme dilakukan dengan basis kegiatan yang dilakukan melalui internet. Kemajuan teknologiinternet saat ini jelas memiliki dampak pada bentuk media massa yang kini online, dimana bentuknya kini bisa berupa website, atau portal berita yang digunakan untuk menyebarkan berita dan informasi. Dalam jurnalisme online teknologi menjadi salah satu faktor penentu, maka tidak jarang media massa juga menggandeng media sosial sebagai alat tambahan dalam proses penyebaran beritanya. Dimana media sosial merupakan media yang menjadi ciri khas generasi milenial. Ciri khas inilah yang tidak dimiliki oleh media massa konvensional. Menurut Mike Ward (2013: 21-26) dalam bukunya Journalism Online, beberapa karakteristik yang menjadi keunggulan dari jurnalisktik media online dibandingkan dengan media konvensional, yakni immediacy, multiple pagination, linkage, lultimedia, flexible delivery platforms, archiving, the relationship with the reader.

\section{a. Immediacy}

Dalam penyebaranya jurnalisme online memiliki keunggulan dalam penyampaian yang cepat. Tiap detik bahkan setiap berita dapat disebarluaskan dan tanpa menginterupsi program atau acara lainnya yang sedang berlangsung dalam sebuah media massa. Bahkan berita yang sudah disebarkan atau diposting dengan mudah dapat terus ditambahkan dilokasi atau alamat website yang sama. Bagi milenial ini merupakan hal yang sesuai dengan kebutuhan hidupnya. Karakteristik yang selalu dituntut dengan serba cepat dan juga dinamis membuat berita online sebagai produk dari jurnalisme online menjadi pilihan yang tepat. Bahkan untuk dapat mengimbangi dengan kelompok atau komunitas terdekatnya mengkonsumsi berita online menjadi salah satu cara yang dilakukan untuk mendapatkan informasi sebagai bahan baku perbincangannya.

b. Multiple Pagination 
Kemampuan sebuah website membuka beberapa bahkan ratuasn page atau halaman menjadi keunggulan dan karakter yang paling khas dalam jurnalistik online. Ini memungkinkan khalayak dapat mengakses berita dengan yang sama atau terkait satu sama lain di waktu yang sama. Bagi milenial ini adalah ruang bagi dirinya untuk memenuhi hasrat keingintahuan akan sebuah informasi. Bagaimana data menjadi acuan bagi milenial untuk mencari sebuah informasi. Dengan kemampuan media online memberikan ruang halaman yang lebih besar memungkinkan generasi milenialuntuk mendapatkan informasi yang lebih mendalam. Ini jelas menjadi tuntutan bagi jurnalis kedepan bahwa kedalaman berita menjadi tolak ukur kaidah penulisan yang harus dilakukan. Berita yang tidak mendalam cenderung nantinya ditinggalkan khalayak media.

c. Linkage

Sikap milenial yang cenderung untuk melihat sebuah berita lalu membandingkannya dengan berita yang lainnya dengan tema yang sama mampu dipenuhi oleh karakeristik khas ini pada jurnalisme online. Membandingkan informasi atau berita dilakukan karena merek menganggap ada kecenderungan keberpihakan media pada kepentingan tertentu di dalam politik. Dimana setiap media massa untuk membentuk berita sesuai dengan kepentingan institusi media tesebut. Sehingga tingkat keakuratannya harus dilihat dengan membandingkan konten berita tersebut di media lainnya. Jika sebelumnya media dianggap dapat digunakan sebagai alat untuk mempengaruhi kesadaran khalayak karena khalayak dianggap pasif, kini argumentasi itu bisa saja dikesampingkan. Khalayak melalui media online kini memiliki kesempatan untuk melakukan konfirmasi kepada beberapa sumber berita lainnya dengan cara membandingkan dan melakukan konfirmasi data dari berbagai sumber.

Sebagian besar generasi milenial memilih untuk membanding berita dengan media massa lain terutama pada konten berita politik. Mereka memiliki tingkat kepercayaan rendah terhadap konten politik, kerena bagi mereka media saat ini memiliki kepentingan politik tertentu. Milenial juga sering dianggap sebagai generasi yang paling tidak peduli dengan persoalan politik, data penelitian (2018) bahkan menyebutkan bahwa generasi milenial menganggap bahwa topik politik sebagai topik yang biasa saja dan partisipasi politik dari generasi milenial juga cenderung rendah (Juditha dan Darmawan, 2018:92).

d. Multimedia

Salah satu ciri khas yang khas adalah dimana jurnalistik online memberikan ruang pada penyajian informasi yang menggabungkan teks, audio (suara), video, gambar, maupun grafis sekaligus. Penggabungan ini jelas memiliki keunggulan yang jauh lebih menarik perhatian khalayak yang mengakses berita tersebut. Sebagai generasi visual, milenial jelas menikmati apa yang telah disajikan oleh jurnalistik online melalui karakteristik ini. Gaya mengkonsumi media dengan cara lama yakni membaca melalui media fisik seperti koran, buku, majalah dan lain sebaginya kini tergantikan dengan adanya karakteristik multimedia. Instusi media online juga diuntungkan dengan karakter ini, dimana mereka tidak lagi membuthkan biaya yang besar untuk menyampaikan berita dalam sebagai bentuk informasi.

Story telling dan informasi berbentuk grafis merupakan metode konten berita yang efektif bagi keterserapan informasi kepada generasi milenial. Generasi ini bahkan bisa menghabiskan waktu berjam-jam hanya untuk menikmati konten jurnalistik online yang disajikan dengan media audio maupun video. Kegemaran mereka terhadap dunia online memang tidak dapat dipungkiri kemudahan media online 
untuk di jangkau melalui genggaman mereka baik itu berbentuk audio maupun visual grafis membuat generasi ini gandrung akan informasi dimedia online.

e. Flexible delivery platforms

Dalam jurnalisme online wartawan atau jurnalis memiliki kemudahan dalam proses menulis berita. Seorang wartwan atau jurnalis dapat saja menulis beritanya diwaktu kapanpun dan dimana saja. Kemudahan ini yang membuat kecepatan penyebaran sebuah berita dapat dilakukan. Generasi milenial terbantu dengan adanya karakteristik ini. Kecepatan dan fleksibilitas ini juga sejalan dengan ciri dari generasi yang sering disebut sebagai generasi internet ini. Bagaimana fleksibilitas dalam mengkonsumsi pemberitaan dimana dan kapanpun. Bahkan ketika sedang melakukan aktifitas sehar-hari yang padat.

f. Archiving

Berita online yang telah di publikasi di media online memungkinkan pengarsipan dengan mengelompokan konten berita sesuai dengan tema-tema (rubrik) tertentu, dan dengan bantuan kata kunci (keyword maupun tags) khalayak jurnalisme online dapat mengaksesnya kapanpun. Sebagai generasi milenial kecepatan merupakan sifat dasarnya, sehingga dengan kemudahan akses dimana berita sudah disesuaikan dengan rubrik dan kata kunci atau tags tertentu membuat generasi ini semakin gandrung dengan teknologi media online. Sifatnya yang up to date membuat generasi milenial dirasa tidak boleh ketinggalan informasi terkini, karena baginya berita terkini yang menjadi trending pada media merupakan modal bahan baku pembicaraan dengan teman komunitasnya. Hal ini dilakukannya guna membina hubungan yang erat dengan anggota lainnya didalam komunitasnya. Selain itu pengelompokan ini juga memudahkan generasi milenial mencari refrensi guna kebutuhannya akan pengetahuan yang menunjang bagi pekerjaanya sehari-hari. Generasi milenial yang berprofesi sebagai pengusaha misalnya, dia menjadikan berita online untuk kepentingannya dalam berwirausaha dan dengan kemudahan pada pencarian yang telah di atur sesuai dengan tema yang sejenis dirinya merasa itu sangat membantu. Ketika melakukan pencarian hal yang dia butuhkan dia akan langsung menuju pada kelompok berita dengan tema tertentu yang sesuai dengan kebutuhannya dan itu bisa dilakukan dengan cepat karena media online memungkinkan pengelompokan pada tema tertentu pada platformnya.

g. The relationship with the reader

Feedback langsung yang dapat dilakukan oleh khalayak media online merupakan hal yang paling khas yang tidak dimiliki media jenis lain. Feedback ini diberikan oleh media online melalui kolom komentar, dimana khalayak atau audience media online jelas merasa dilibatkan karena bisa ikut berkomentar langsung dalam hitungan detik. Generasi milenial sebagai khalayak media online memiliki kesempatan untuk melakukan interaksi dengan jurnalis atau wartawan dan juga khalayak lainnya melalui kolom komentar. Interaksi yang mungkin selama ini tidak bisa terjadi pada media konvensional dimana generasi milenial biasanya dianggap hanya sebagai penerima informasi melalui konten berita dan tidak memiliki kuasa memberikan timbal balik.

Melalui media online khalayak justru dapat memberikan opininya terkait dengan berita yang dikonsumsinya pada kolom tersebutruang kebebasan dalam berpendapat, mengungkapkan apa yang menjadi buah pikirnya yang kemudian dapat dilihat dan dikomentari balik oleh khalayak lain. Bahkan generasi milenial mengaku sering menjadikan komentar sebagai bagian dari keputusannya dalam mengkonsumi berita di media massa bersangkutan. Kolom komentar memberikan ruang referensi dirinya untuk meneruskan kegiatan mengkonsumsi berita selanjutnya pada media 
massa tersebut atau tidak. Komentar bahkan bisa diistilahkan sebagai motor penyaring berita yang akan generasi milenial konsumsi.

Ini memperlihatkan pada sebuah realitas yang baru dimana media online memberikan peluang besar pada khalayak media online untuk berinteraksi dan berpartisipasi. Media online berada pada era media kedua (second media age) dimana sifatnya yang interaktif dan memungkinkan khalayaknya tidak sekedar mengkonsumsi secara pasif seperti era media pertama (Holmes, 2005:10). Ditambah interaksi ini semakin masif dapat dilakukan dikarenakan media massa online kini juga terhubung pada platform media sosial yang dekat dengan generasi milenial. Hal ini memperlihatkan bahwa generasi milenial bukan saja sebagai khalayak penerima pesan tetapi juga sangat memungkinkan sebagai pemberi pesan atau produsen informasi. Berbeda dengan era media konvensional seperti cetak dan penyiaran yang cenderung menjadikan media massa sebagai produsen berita atau informasi.

\section{Storytelling sebagai Pengalaman Mengkonsumsi Berita Online Generasi Milenial}

Dalam ranah jurnalistik perbedaan artikel maupun produk naratif (storytelling) dengan non naratif tercermin pada perbedaan gaya, dimana hal ini berfungsi untuk meningkatkan pengalaman pembaca agar tenggelam dalam cerita (Krieken, $2018: 2$ )

Dalam proses storytelling (naratif) ada tiga karakteristik utama yang melekat pada proses ini, yakni:

(1) Rekonstruksi adegan. laporan berita langsung biasanya sering mengalami kekurangan pada detail deskripsi kejadian yang layak diberitakan, melakukan rekonstruksi yang terperenci yang merupakan inti dari berita.

(2) Struktur peristiwa. berita yang diurutkan secara kronologis telah terbukti menimbulkan lebih banyak ketegangan daripada berita yang tidak berurutan secara kronologis.

(3) Teknik sudut pandang. Pengambilan sudut pandang aktor di dalam berita merupakan salah satu teknik yang bisa digunakan dalam storytelling, sehingga mampu memberikan kesan lain dalam sebuah berita.

Dari sudut pandang generasi milenial storytelling membantu memfasilitasi imajinasi mereka melalui cara visual. Generasi milenial sebagai generasi visual memang lebih memiliki ketertarikan pada gaya pemberitaan media online yang mampu memberikan gambaran secara visual menegenai sebuah peristiwa. Melalui metode storytelling mereka diajak ke dunia cerita dan mengamati peristiwa nyata secara virtual dimana seolah-olah sedang berlangsung di depan mata mereka (Krieken, $2018: 2$ ).

\section{KESIMPULAN}

Generasi milenial dalam mengkonsumsi berita online memiliki kecenderungan memilih mengkonsumsi berita lewat aplikasi pihak kedua seperti Twitter, Instagram, Line Today, bahkan Youtube. Khalayak lebih banyak mengetahui berita terkini melalui media massa yang aktif meng-update konten beritanya melalui media sosial, maupun aplikasi pihak kedua yang memang memfokuskan diri pada distribusi berita dari berbagai mitra media massa utama. Kemudian sebagian besar memilih membandingkan berita yang diterimanya tersebut dengan berita dari media massa lainnya dikarenakan mereka melihat ada kecenderungan tertentu setiap media massa untuk membentuk berita sesuai dengan kepentingan institusi berita tesebut. Dalam hal pemilihan konten media generasi milenial lebih senang berlama-lama pada berita berita dengan penyampaian yang dilakukan dengan metode strorytelling dibandingkan dengan metode penyampian berita lainnya. Hal ini dapat menjadi masukan bagi proses 
penyampaian informasi di media massa dikemudian hari agar dapat menggaet khalayak untuk meningkatkan konsumsi berita di medianya. Bahwa metode storytelling merupakan salah satu cara yang dapat menjadi pertimbangan dalam penyajian berita.

\section{DAFTAR PUSTAKA}

Barran, Stanley J. (2012). Pengantar Komunikasi Massa Jilid 1 Edisi 5. Jakarta: Erlangga.

Bryan, A. (2011). The New Digital Storytelling. USA: ABC-Clio

Hartley, J., \& Hartley, J. (1996). Popular Reality: Journalism, Modernity, Popular Culture. London: Arnold.

Holmes, D. (2005). Communication Theory Media, Technology, Society. Communication Theory. Thousand Oaks, CA: SAGE Publications, Ltd.

Juditha, C., \& Darmawan, J. (2018). Penggunaan Media Digital Dan Partisipasi Politik Generasi Milenial. Jurnal Penelitian Komunikasi Dan Opini Publik Vol, 22(2), 94-109.

Karman, K. (2013) Riset Penggunaan Media Dan Perkembangannya Kini Researches On Media Uses And Its Development. Jurnal Studi Komunikasi Dan Media. Vol. 17(1). 93-111.

KPPA (Kementerian Pemberdayaan Perempuan dan Perlindungan Anak). (2018). Statistik Gender Tematik: Profile Generasi Milenial di Indonesia. Kementerian Pemberdayaan Perempuan dan Perlindungan Anak.

Krieken, Kobie Van. (2018). Multimedia Storytelling in Journalism: Exploring Narrative Techniques in Snow Fall.

Kriyantono, Rachmad. (2009). Teknik praktis riset komunikasi. Jakarta: Kencana Prenada Group.

Melissa. (2012). Storytelling menuntut kejujuran, otentitas, dan kredibilitas sebagai elemen kritis. Skripsi: Universitas Indonesia.

Putra, Y. S. (2017). Theoritical Review: Teori Perbedaan Generasi. Jurnal Ilmiah Among Makarti, 9(18). 123-134.

Rakhmat, Jalaludin. (2011). Psikologi Komunikasi. Bandung: Remaja Rosdakarya.

Rusadi, Udi. (2014), Konsumsi Berita Lintas Media Massa Konvensional dan Internet. Jurnal Penelitian Dan Pengembangan Komunikasi Dan Informatika Vol. 4 (3). 73 - 186.

Effendy, Onong Uchjana. (2003). Ilmu Teori dan Filsafat Komunikasi. Bandung : Remaja Rosda Karya.

Ward, Mike. (2013). Jurnalism Online. Oxford: Focal Press. 